\title{
ANATOMICAL ADAPTATION TO HAPLODIPLOIDY IN THE OXYUROID (NEMATODA) \\ DESMICOLA SKRJABINI n. sp. from a Diplopod in Gaboon
}

\author{
MARTIN L. ADAMSON
}

SUMMARY. Desmicola skrjabini n. sp. (Oxyuroidea; Nematoda) is described on the basis of female morphology from the hind-gut of Pachybolus sp. (Pachybolidae ; Spirobolida ; Diplopoda) from Gabon. The new species differs from the type and only other species in lacking interlabial formations and obvious cephalic papillae, and in having what appear in apical view as fingerlike cuticular ornamentations on the anterior surface of the lips. D. skrjabini is didelphic and a seminal receptacle is present in only one branch of the reproductive tract. In oxyuroids, males develop from unfertilized eggs whereas females develop from fertilized eggs. It is suggested that the curious reproductive anatomy of Desmicola ensures production of eggs of both types and therefore offspring of both sexes.

\section{Adaptation anatomique à l'haplodiploïdie chez l'Oxyure (Nematoda) Desmicola skrjabini n. sp.) parasite d'un Diplopode au Gabon}

RÉSUMÉ. Description de la femelle de Desmicola skrjabini n. sp. (Oxyuroidea ; Nematoda) parasite de l'intestin postérieur de Pachybolus sp. (Pachybolidae ; Spirobolida ; Diplopoda) du Gabon. La nouvelle espèce diffère de l'espèce type, seule autre espèce du genre par l'absence de formations interlabiales, par le fait que les papilles céphaliques sont représentées par quatre rameaux nerveux, chacun se divisant en trois branches à la base des lèvres, et par la présence d'ornementations digitiformes sur la surface antérieure des lèvres. D. skrjabini est didelphe et un réceptacle séminal n'existe que sur une seule branche de l'appareil génital de la femelle. Chez les Oxyures les mâles sont haploïdes et issus d'œufs non-fécondés tandis que les femelles sont diploïdes et issues d'œufs fécondés. L'auteur suggère que l'anatomie curieuse de l'appareil génital chez Desmicola assure la production d'œufs fécondés et non-fécondés et ainsi, de descendants des deux sexes.

\section{Introduction}

Recent studies (Adamson, 1981; Adamson and Petter, 1983) have show that oxyuroid nematodes reproduce by haplodiploidy. Thus, males are haploid and develop from unfertilized eggs whereas females are diploid and develop from ferti-

École pratique des Hautes Études et Laboratoire de Zoologie (Vers), associé au CNRS, Muséum National d'Histoire Naturelle, 61, rue Buffon, F 75231 Paris Cedex 05.

Accepté le 2I avril r983. 
lized eggs. One of the consequences of this form of reproduction is that reproductive success depends on females producing a mixture of fertilized and fertilized eggs. Females of Desmicola skrjabini n. sp. (Oxyuroidea ; Nematoda) from Pachybolus sp. (Pachybolidae ; Diplopoda) in Gabon illustrate what appears to be an extraordinary anatomical adaptation to this end. They are didelphic but a seminal vesicle is present in only one branch of the reproductive tract.

\section{Materials and methods}

The single female specimen of Pachybolus sp. (Pachybolidae; Spirobolida; Diplopoda) was identified by J. P. Mauries (Laboratoire des Arthropodes, Muséum national d'Histoire naturelle). Nematodes collected from the posterior gut, were fixed in hot $70 \%$ ethanol and stored in $70 \%$ ethanol before being cleared and studied in lactophenol. Type material is stored in the Paris Museum (MNHN : Laboratoire de Zoologie-Vers : RA 34).

\section{Description of species}

\section{Desmicola skrjabini n. sp.}

Small worms with swollen cephalic extremities. Body narrowing abruptly just posterior to head, thereafter gradually increasing in width, reaching maximum width just anterior to anus and terminating in long filiform tail ( $\mathrm{fig} .1 \mathrm{~A}$ ). Body cuticle with prominent annulations largest behing midbody.

Mouth opening (fig. $1 G, H, I$ ) surrounded by three lips; dorsal lip bilobed, subventral lips trilobed. Cuticular thichenings present forming finger-like oranmentations on anterior surface of lips. Amphids prominent, on subventral lips. Cephalic papillae not observed but cephalic nerves arranged as follows :

- four submedian, each dividing into three branches at base of lips ; branch which separates first presumably representing nerve serving inner submedian papilla, remaining two branches innervating outer labial and cephalic papillae ;

- two lateral nerves just ventral to amphids and corresponding to the lateral inner labial papillae.

Anterior end of buccal capsule with three (one dorsal and two subventral) pairs of cuticular swellings; tiny cuticular tooth-like formation present between elements of each pair. Posterior section of buccal capsule surrounded by oesophageal tissue,

FIG. I. - Desmicola skrjabini n. sp. A, entire worm, lateral view. B, vulva and anal region, ventral view. C, vulva and anal region, lateral view. D, excretory pore, ventral view. E, œesophageal region, lateral view. F, cephalic extremity, lateral view. G, superficial apical view. $\mathrm{H}$, oblique view of dorsal lip showing submedian cephalic nerves. I, oblique view of left subventral lip showing lateral and submedian cephalic nerves. J, apical view, optical section through buccal cavity. $K$, cephalic extremity, median view, optical section through amphids.

$$
(\mathrm{A}=300 \mu \mathrm{m} \text { scale } ; \mathrm{B} \text { to } \mathrm{E}=90 \mu \mathrm{m} \text { scale } ; \mathrm{F} \text { to } \mathrm{K}=\mu \mathrm{m} \text { scale }) \text {. }
$$




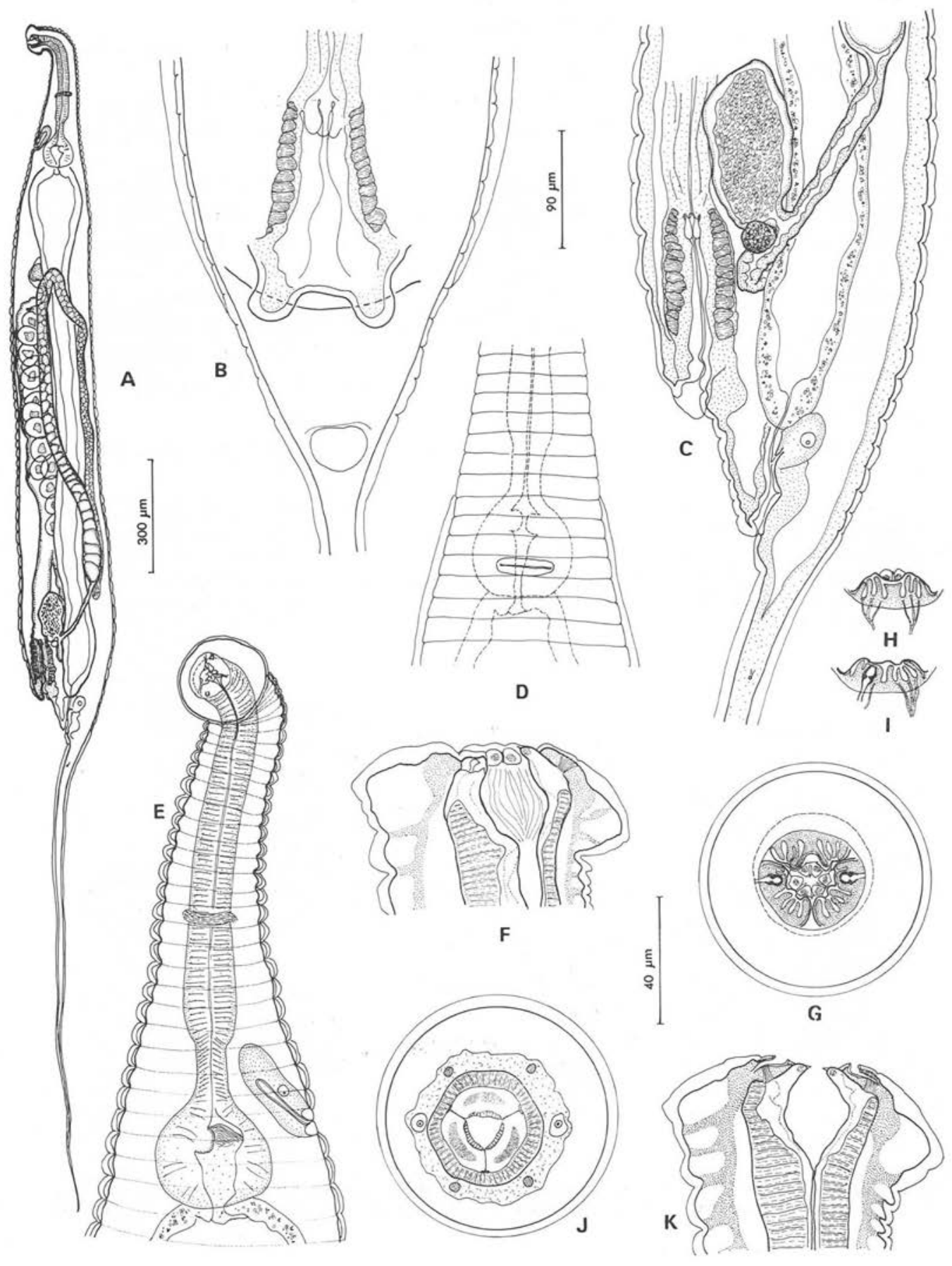


consisting of one dorsal and two subventral cuticular plates with prominent longitudinal striations ( $f$ ig. $1, F, J, K$ ).

Excretory pore near level of oesophageal bulb, lined by thick cuticular ring ( fig. 1, D, E). Narrow lateral alae present extending from near level of oesophageal isthmus to level of anus.

Two ovaries present, their blind ends in posterior half of body, running anteriorly and flexing posteriorly about $200 \mu \mathrm{m}$ posterior to base of oesophagus. One ovary emptying through oviduct into uterus in anterior half of worm; other ovary leading to near level of vulva before emptying into oviduct with prominent sac-like seminal receptacle (fig. 2). Uteri emptying into common vagina near midbody. Vagina leading posteriorly, its posterior portion with thick muscular wall. Vulva just anterior to anus, its anterior lip prominent and bilobed ( $f i g .1 \mathrm{~B}, \mathrm{C}$ ). Anus with plate-like posterior lip. Eggs oval with shell about $2 \mu \mathrm{m}$ thick and containing embryos in early stage of development.

Dimensions of holotype (followed by range of 4 paratypes in parentheses).

Length $3.00(2.98$ - 3.44) mm. Maximum width $238(213$ - 303) $\mu \mathrm{m}$. Head $67(74-82)$ $\mu \mathrm{m}$ wide. Buccal cavity $24(26$ - 32) $\mu \mathrm{m}$, œsophageal corpus $270(274-344) \mu \mathrm{m}$ and isthmus 35 (38 - 49) $\mu \mathrm{m}$ long. Bulb $79(75-86) \mu \mathrm{m}$ long and $76(75-89) \mu \mathrm{m}$ wide. Nerve ring $199(209-258) \mu \mathrm{m}$, excretory pore $344(357-421) \mu \mathrm{m}$ and vulva $1.72(1.77-2.00) \mathrm{mm}$ from anterior extremity. Tail $1.20(1.11-1.31) \mathrm{mm}$ long. Eggs $63-74 \mu \mathrm{m}$ long and $49-52 \mu \mathrm{m}$ wide.

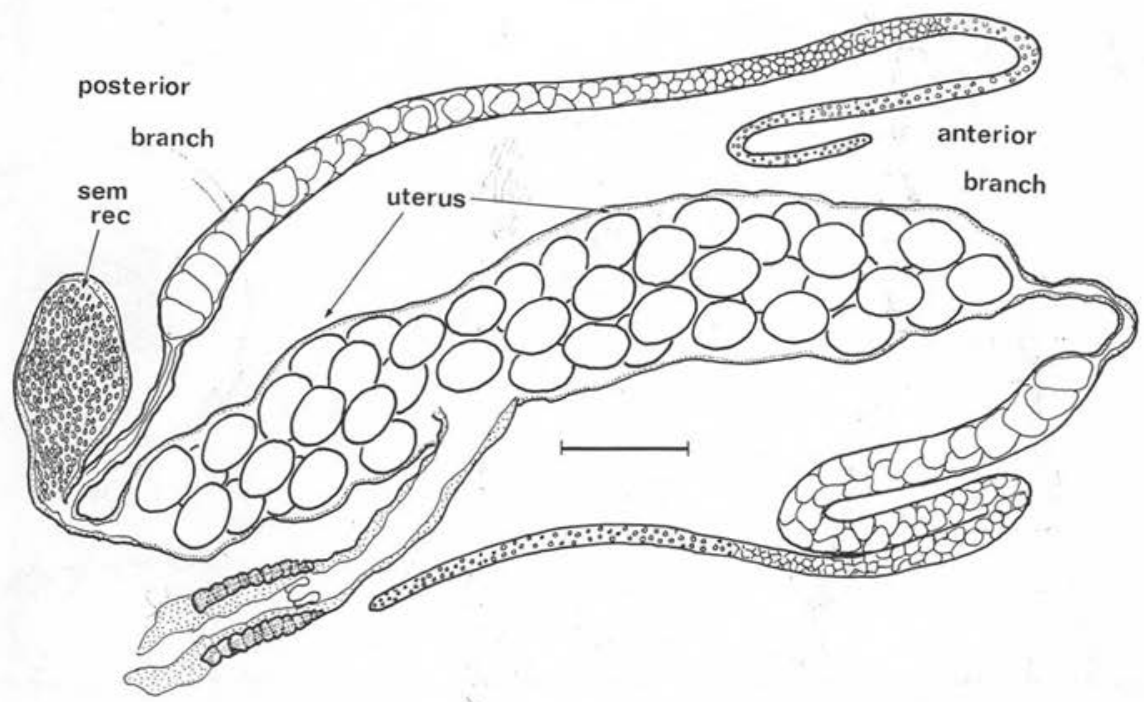

FIG. 2. - Schematic representation of reproductive tract of Desmicola skrjabini $\mathrm{n}$. sp. showing posterior branch with saclike seminal receptacle and anterior branch without seminal receptacle.

Scale bar $=100 \mu \mathrm{m}$. 


\section{Discussion}

\section{1 - Species Diagnosis}

Basir (1956) proposed Desmicola to accomodate D. leidyi (Skrjabin, 1916) from Polydesmus sp. (Polydesmida; Diplopoda) in what was formerly referred to as British East Africa. Desmicola skrjabini n. sp. is the second species described in the genus and differs from the type species by the following :

- the new species lacks interlabial formations;

- cephalic papillae are prominent in D. leidyi but are recognizeable only on the basis of the cephalic nerves in D. skrjabini;

- cuticular thickenings form what appear in apical view as finger-like ornamentations on the anterior surface of the lips of D. skrjabini; these are apparently absent in D. leidyi;

- the anterior lip of the vulva of D. skrjabini is prominent and bilobed; this is not true of $D$. leidyi according to Skrjabin's illustrations and description ;

- Skrjabin described the lips of $D$. leidyi as consisting of small anterior and large posterior portions; what he considered the anterior portion of the lips is in fact the anterior end of the buccal capsule which projects beyond the lips in D. leidyi but not in D. skrjabini.

\section{2 - Adaptation to Haplodiploidy}

The curious reproductive anatomy of Desmicola skrjabini apparently represents an adaptation ensuring a mixture of fertilized and unfertilized eggs, and therefore of females and males among a female's progeny.

The anterior branch of the reproductive system lacks a seminal receptacle and ova produced in this branch could not be fertilized unless spermatozoa migrate from the uterus or from the seminal receptacle of the posterior branch. There is no evidence that this occurs : spermatozoa were not observed in the uterus. Thus, the anterior reproductive horn apparently produces unfertilized ova which will develop as males, fertilized ova (female progeny) being produced in the posterior branch. Such an arrangement would also facilitate the control of the sex ratio among the offspring.

\section{REFERENCES}

Adamson M. L. : Studies on gametogenesis in Gyrinicola batrachiensis (Walton, 1929) (Oxyuroides; Nematoda). Can. J. Zool., 1981, 59, 1368-1376.

Adamson M. L., Petrer A. J. : Haplodiploidy in pharyngodonid (Oxyuroidea; Nematoda) parasites of Testudo graeca. Ann. Parasitol. Hum. Comp., 1983, 58, 267-273.

BAsIR M. A. : Oxyuroid parasites of Arthropoda. A monographic study. I. Thelastomatidae, 2. Oxyuridae. Zoologica, Original-Abhandlungen aus dem Gesamtgebiet der Zoologie, $38 \mathrm{Bd}, 2$. Lief., Heft I06, Stuttgart. 1956, 79 p., 13 pl.

SkrJabin K. I. : Parasitic nematodes and trematodes collected by the expedition of Prof. V. Dogiel and I. Sokolov in British East Africa. Scientific Research Expedition to British East Africa und Uganda, V. Dogiel and I. Sokolov. 1916. No. 4., I-98 (Russian), 99-157 (English Translation). 